\title{
Bio-Markers of Inflammatory Bowel Disease: Past, Present, and Future
}

\section{Bahgat MH* and El-Etreby SA}

Department of Hepatology and Gastroenterology, Specialized Medical Hospital, Mansoura University, Egypt

*Corresponding author: Monir Bahgat, Department of Hepatology and Gastroenterology, Specialized Medical Hospital, Faculty of Medicine, Mansoura University, Gomhuria Street, Mansoura 35516, Egypt

Received: March 07, 2017; Accepted: April 25, 2017; Published: May 09, 2017

\begin{abstract}
Ulcerative colitis (UC) and Crohn's disease (CD) exemplify the two main arms of the spectrum of an idiopathic chronic disease known as inflammatory bowel disease (IBD). To date, this disease remained a puzzling dilemma in many aspects; including difficulties in its etiology/pathogenesis, diagnosis, severity assessment, treatment and outcomes/complications. Physicians usually get the diagnosis of IBD through a combination of clinical features, laboratory tests, radiology, as well as the invasive technique of endoscopy/biopsy. In spite of these efforts, the definite diagnosis can't be established in a significant cohort of cases. This paved the way to searching for laboratory biomarkers that are noninvasive, reproducible, rapid and relatively cheap than other modalities. Unfortunately, we're still far from these ideal biomarkers. Some biomarkers are already being used in daily practice including C-reactive protein (CRP) and fecal calprotectin while others are still in need for confirmation before being applied in clinical practice. In this review article, the authors are going to discuss the past, present, and future utility of biomarkers in IBD. This article aims at highlighting the uses and limitations of all possible current and novel biomarkers in every aspect of the disease from predisposition to prognosis.
\end{abstract}

Keywords: Inflammatory bowel disease; Ulcerative colitis; Crohn's disease; Biomarkers; ANCA; ASCA; calprotectin; Lactoferrin; Neopterin; ESR; C-reactive protein; Lipocalin-2; Infliximab

\section{Abbreviations}

IBD: Inflammatory Bowel Disease; UC: Ulcerative Colitis; CD: Crohn's Disease; ANCAs: Antineutrophil Cytoplasmic Antibodies; FC: Fecal Calprotectin; ASCAs: Anti-Saccharomyces Cerevisiae Antibodies; FL: Fecal Lactoferrin; FN: Fecal Neopterin; CRP: C-Reactive Protein; ESR: Erythrocyte Sedimentation Rate; RDW: Red Blood Cell Distribution Width; ADA: Adenosine Deaminase; LCN2: Lipocalin-2; sST2: Serum Soluble ST2; eNO: Exhaled Nitric Oxide; ATIs: Antibodies to Infliximab; TPMT: Thiopurine Methyltransferase; 6TGN: 6-Thioguanine Nucleotide

\section{Introduction}

\section{Biomarkers of etiology/pathogenesis}

Background: Multiple genes for IBD had been discovered, but only three had been claimed for a direct role in the etiology and pathogenesis of IBD.

NOD2: Sequencing for NOD2 variants appears of substantial importance in $\mathrm{CD}$ patients for predicting ileal location, stenotic lesions and complicated course [1,2]. This seems relatively more important among Caucasians particularly Turkish and Iranian patients with CD $[3,4]$.

IL-23 receptor gene (IL23R): IL23R is a CD susceptibility gene which is expressed as two opposing types of variants in different populations; IBD risk-increasing and IBD risk-decreasing variants [5-7].

This variance could also modify treatment plans. As an example, homozygous carriers of IBD risk-increasing variants are more likely to respond to anti-TNF than homozygous carriers of IBD riskdecreasing variants [8].

Autophagy Genes: CD risk is increased through autophagyregulating genes including autophagy 16-like 1 (ATG16L1), immunity-related guanosine triphosphatase $\mathrm{M}(I R G M)$, and leucinerich repeat kinase 2 (LRRK2) genes $[9,10]$. This association, however, is race-dependent [11-13]. So future researches are needed to map it.

To summarize, biomarkers depending on gene sequencing seems associated with predisposition to $\mathrm{CD}$ rather than UC with none of them being currently in use awaiting confirmation by future research.

\section{Biomarkers of diagnosis}

Background: The rationale for diagnostic biomarkers relies upon the immune mechanism of chronic inflammation in IBD. Their use is of particular importance when diagnosing and/or differentiating $\mathrm{UC}$ and $\mathrm{CD}$ by the combination of clinical, endoscopic, and histopathologic features seems confusing. The two main currently used immune-related biomarkers are pANCA and ASCA while the utility of many other immune markers in the diagnosis and differential diagnosis of IBD needs future research to validate their practical use including anti-OmpC, ALCAs, ACCAs, AMCAs, antiL, and anti-C and pancreatic autoantibodies (PAB) [14-17].

Fecal calprotectin (FC): Fecal calprotectin was first described in 1980 by Fagerhol, et al. [18]. It is a protein released by the white blood cells involved in inflammation of the bowel. In that way, a high level correlates with bowel inflammation. After binding to calcium, 
it becomes a stable compound in the intestines. It can be measured by laboratory tests, including the more recent point-of-care testing (POCT) [19]. This interesting characteristic of its stable distribution in feces reflects the need to examine only one sample of stool [20].

A systematic review by Waugh, et al. concluded that FC can be used to differentiate between IBD and IBS at a cut-off level of 50 $\mu \mathrm{g} / \mathrm{g}$ in both adults and children with sensitivities of $83-100 \%$ and specificities of $60-100 \%$ in adults and sensitivities of $95-100 \%$ and specificities of $44-93 \%$ in children [19].

Anti-neutrophil cytoplasmic antibodies (ANCAs): In 1990, Rump, et al. suggested the possible use of a new type of perinuclear anti-neutrophil cytoplasmic antibody (p-ANCA) in active UC but not CD [21]. The utility of these antibodies in association with ASCA in diagnosing difficult cases of indeterminate colitis (IC) was illustrated by Joossens, et al. when they determined that ASCA+/pANCA- status predicts CD in $80 \%$ of patients with IC while ASCA-/pANCA+ status predicts UC in $63.6 \%$ of patients with IC [22]. However, it should be noted also that pANCA might be positive in rheumatoid arthritis and even in nearly one third of healthy individuals $[14,23]$.

Anti-Saccharomyces cerevisiae Antibodies (ASCAs): In 1988, a study by Main, et al. reported antibody to Saccharomyces cerevisiae (bakers' yeast); a common dietary antigen, in patients with IBD and in controls. They found a considerable difference in titers of ASCAs between patients with CD and those with UC which was different from previous reports that suggested a generalized increase in antibody to food antigens in people with IBD which may reflect increased exposure to antigens owing to an inflamed or damaged bowel wall, i.e., secondary to the primary disease process. In their study, the response to $S$ cerevisiae seemed to be quite specific to $C D$ which can't be explained as a secondary phenomenon. Furthermore, the difference between the two diseases cannot be accounted for on an anatomical basis, as increased titers of ASCAs were not confined to patients with $\mathrm{CD}$ of the small bowel. ASCAs are antibodies against mannan in cell wall of S. cerevisiae [24] with high specificity of 90$100 \%$ in CD but relatively low sensitivity of $31 \%-45 \%$ [25]. Finally, it should be noted that ASCA and atypical P-ANCA markers are not useful for IBD screening. A study by Mokhtarifar, et al. suggested that while atypical P-ANCA may be useful in differentiating UC from CD, ASCA is of limited value for screening and differentiating UC from CD [26].

\section{Biomarkers of disease activity}

Background: Various markers of activity and inflammation have been introduced with a concern about their individual sensitivity and specificity. Using a combination of these markers may be more useful for predicting disease activity and confirming inflammation. Some of these markers are already in current use; others are still emerging.

\section{Markers in current use:}

Fecal calprotectin (FC): As discussed earlier, FC reflects the process of inflammation, so it is a reasonable marker for assessment of IBD activity [27]. One meta-analysis confirmed that fecal calprotectin is better than the other currently used markers particularly CRP, ESR, ASCA, and pANCA [28]. Another meta-analysis showed that fecal calprotectin can reduce endoscopy rate by $67 \%$, while delaying treatment of patients by $6 \%$ [29]. Another important feature is the differential level of FC according to the site of IBD where it is found to be significantly higher in active colonic rather than ileal CD [30]; and in left-sided/distal UC than ulcerative pancolitis [31]. Finally, FC could be used as a marker for treatment assessment [32] as it decreases considerably after anti-TNF therapy, and it correlates with $\mathrm{CD}$ endoscopic index of severity (CDEIS) [33] as well as endoscopic mucosal healing [34]. Koulaouzidis, et al. suggested that FC can direct the use of special costly investigations as capsule endoscopy which can be declined if FC level is less than $100 \mu \mathrm{g} / \mathrm{g}$ [35].

Fecal Lactoferrin (FL): Lactoferrin is an iron-binding protein component of neutrophils that covers most of the mucosal surface and is activated in acute inflammation [36] suggesting its use in inflammation of intestine. FL increases significantly with bowel infiltration by neutrophils and is stable in feces for 5 days [37]. The diagnostic accuracy of lactoferrin for IBD could reach up to $80 \%$ when compared with IBS, which is rather similar to FC and better than CRP [38]. FL is also associated with disease activity [39].

Fecal Neopterin (FN): Neopterin is a product of human monocytes and macrophages stimulated by $\gamma$-interferon. Both fecal calprotectin and fecal neopterin concentrations are correlated with endoscopic scores in UC better than in CD. Using cutoffs of $250 \mu \mathrm{g} / \mathrm{g}$ for fecal calprotectin and $200 \mathrm{pmol} / \mathrm{g}$ for fecal neopterin, both fecal markers have similar overall accuracy to predict endoscopic activity in patients with $\mathrm{CD}(74 \%)$ and a relatively higher accuracy in patients with UC ( $88 \%$ and $90 \%$, respectively) [40].

C-reactive protein (CRP): CRP is an acute phase protein secreted by hepatocytes in healthy individuals at a very low level of $<1 \mathrm{mg} / \mathrm{L}$. Being one of the most important protein in acute inflammation [41], it sharply increases to very high levels that may reach 350-400 $\mathrm{mg} / \mathrm{L}$ with acute inflammation while lesser levels of elevation in the range of $10-40 \mathrm{mg} / \mathrm{L}$ may indicate chronic inflammation as IBD. However, for unknown mechanism, it correlates significantly with CD but not UC $[42,43]$ while high-sensitivity C-reactive protein (hs-CRP) and $\beta 2$-microglublin correlate with histology scores of UC [44]. To summarize, CRP can be falsely low despite active mucosal inflammation while it is more reliable in transmural inflammation [45].

Erythrocyte Sedimentation Rate (ESR): Like CRP, ESR is a measure of systemic inflammation and thus no-specific to IBD. Unlike CRP, ESR levels peak later and decrease at a slower rate. So, ESR is better in monitoring disease activity and response to treatment after the first $24 \mathrm{~h}$ of onset whilst CRP may be more useful in the first $24 \mathrm{~h}$ [46]. However, the longer half-life of ESR as well as its interference with other factors makes ESR less useful in clinical practice compared with CRP [47].

Platelets count and mean volume: Increase in platelets counts in IBD might represent the hypercoagulable state of IBD [48-50] particularly the reticulated platelet levels which increase significantly in UC [51]. Mean platelet volume (MPV) points toward average size of platelet reflecting the rate of platelet stimulation and production. One study [52] found that MPV decreased significantly in active IBD, and it was negatively correlated with CRP and ESR while another study [53] failed to confirm this relationship.

Red blood cell distribution width (RDW): RDW reflects the 
size and variability of red blood cells in peripheral circulation [54]. A study involving 221 IBD (120 UC and $101 \mathrm{CD}$ ) found that RDW is better than CRP and ESR in predicting CD activity in absence of anemia [55].

\section{Emerging/novel markers:}

Fecal S100A12: S100A12 is a novel biomarker which is similar to calprotectin in its calcium-binding properties [56] that increases cytokine release [57]. Although it is also detectable in serum, the fecal assay is more sensitive and specific for IBD [58].

Adenosine Deaminase (ADA): ADA may be a new biomarker for CD activity [59].

Lipopolysaccharide-binding protein (LBP) and soluble CD14 (sCD14): In IBD, enhanced inflammatory activity in the gut is thought to increase the risk of bacterial translocation and endotoxemia. Lakatos, et al. investigated the association between serum level of LBP and sCD14 with clinical disease activity and they suggested both as markers of disease activity in $\mathrm{CD}$ with accuracy similar to that of hs-CRP [60].

Lectin-based immunoassay for aberrant IgG Glycosylation: Shinzaki, et al. [61] found that agalactosyl fraction among fucosylated IgG oligosaccharides is increased in IBD, especially CD and they recommended the use of lectin enzyme immunoassay for agalactosyl IgG as a novel biomarker for IBD, particularly CD.

Serum soluble ST2 (sST2): ST2 is a member of the interleukin 1 receptor family [62] and sST2 has been introduced as a new and promising activity marker in ulcerative colitis [63].

Lipocalin-2 (LCN2): LCN2 is a potent bacteriostatic protein. In a recent study [64], its serum level was determined in 131 IBD patients (71 with CD, and 60 with UC) and 63 healthy controls. A significant upregulation of serum LCN2 in active IBD compared with healthy controls was confined to active UC. Therefore, this study introduced LCN2 as a marker of UC disease activity.

Other suggested novel biomarkers: Many other markers have been suggested including Soluble Triggering Receptor Expressed on Myeloid Cells-1 (sTREM-1) [65], Substance P [66], Activated Thrombin Activatable Fibrinolysis Inhibitor (TAFIa) [67], Quantitative Fecal Immunochemical Test (FITs) [68], fecal Chitinase 3-Like-1 [69], Angiogenin [70], Indoleamine 2,3 Dioxygenase [71], Mucosal cytokine gene expression profiles [72], and Urine Neopterin [73].

\section{Biomarkers of outcomes/complications}

Background: IBD particularly UC is precancerous; with the potential of progression to colorectal cancer (CRC) particularly in longstanding cases. Also, IBD particularly CD is associated with a variety of systemic manifestations, including large and small airway involvement. These potential risks illustrate the importance of screening longstanding IBD cases for complications.

Exhaled nitric oxide (eNO): eNO measurement has been suggested in the follow-up of patients with $\mathrm{CD}$ to pick up subclinical pulmonary involvement in CD [74].

Fecal pyruvate kinase: Fecal Pyruvate Kinase has been suggested as a potential new marker for intestinal inflammation in children with IBD [75], a new predictor for inflammation and severity of pouchitis [76], and as a new, sensitive screening tool for CRC [77].

miRNAs: PDCD4/miR-21 dysregulation was confirmed in IBD-associated carcinogenesis with miR-21 increases but PDCD4 decreases [78]. Another study [79] confirmed the dynamic changes in the expression of MicroRNA-31 during IBD-associated neoplastic transformation. A third study [80] suggested the detection of miR92a and miR-21 in stool samples as potential screening biomarkers for CRC and polyps.

Mucosal chitinase 3-like-1: A study by Chen, et al. suggested Chitinase 3-like-1 expression in colonic epithelial cells as a potentially novel marker for colitis-associated neoplasia [81].

\section{Biomarkers of therapy}

Background: Some markers are proposed to monitor the effect of the drugs used in treating IBD.

Antibodies to anti-TNF: Secondary loss of response to antiTNF agents after a period of initial response can be attributed to the formation of anti-drug antibodies that neutralize the drug activities or lead to faster clearance of the drug [82].

A meta-analysis [83] suggested that the presence of antibodies to infliximab (ATIs) is associated with a significantly higher risk of loss of clinical response to infliximab associated with lower serum levels of infliximab in patients with IBD. However, published studies on this topic lack uniform reporting of outcomes and high risk of bias was present in all the included studies.

Therapeutic drug monitoring: Therapeutic drug monitoring in patients with Crohn's disease being treated with adalimumab seems critical. While therapeutic drug monitoring should be performed at trough, a very recent study by Ward, et al. [84] suggested that a drug level $\geq 4.9 \mu \mathrm{g} / \mathrm{mL}$ obtained during the first 9 days predicts a therapeutic trough drug level with reasonable confidence.

Thiopurine methyltransferase (TPMT) and 6-thioguanine nucleotide (6TGN): Low TPMT activity and high 6TGN concentrations have been linked to therapeutic success in IBD patients treated with thiopurines. However, a recent Spanish study does not support determination of TPMT activity or 6TGN concentrations to predict treatment outcome [85].

Urine Salicylate Level: Mesalamine non-adherence is common among patients with UC which can be difficult to identify in practice. A random urine salicylate level measured in the clinic can identify patients who have not recently taken mesalamine [86].

Genes: Some studies found an association between genetic factors and response to treatment. Polymorphisms in multidrug resistance- 1 (MDR1) gene represent a notable example associated with refractory CD and UC. MDR1 polymorphisms is associated with corticosteroid refractoriness in $\mathrm{CD}$ and $\mathrm{UC}$, and it is also correlated with a higher risk of cyclosporine failure in patients with steroid-resistant UC $[87,88]$. Another example is that homozygous carriers of IBD riskincreasing $I L 23 R$ variants are more likely to respond to anti-TNF than homozygous carriers of IBD risk-decreasing IL23R variants [8]. A third example is that polymorphisms in apoptosis genes predict 
response to infliximab therapy in luminal and fistulizing CD [89].

\section{Conclusion}

Currently used IBD markers are far from being ideal. Continuous research for novel markers with ideal characteristics is still required. So, the emergence of novel IBD biomarkers will remain an area of active investigation by enormous number of researchers. An interesting area for this research would be the technology based approach utilizing the advances in genomics, proteomics and metabolomics.

\section{References}

1. Cho JH, Brant SR. Recent insights into the genetics of inflammatory bowe disease. Gastroenterology. 2011; 140: 1704-1712.

2. Ogura Y, Bonen DK, Inohara N, Nicolae DL, Chen FF, Ramos R, et al. A frameshift mutation in NOD2 associated with susceptibility to Crohn's disease. Nature. 2001; 411: 603-606.

3. Ng SC, Tsoi KK, Kamm MA, Xia B, Wu J, Chan FK, et al. Genetics of inflammatory bowel disease in Asia: systematic review and meta-analysis. Inflamm Bowel Dis. 2012; 18: 1164-1176.

4. Economou M, Trikalinos TA, Loizou KT, Tsianos EV, Ioannidis JP. Differentia effects of NOD2 variants on Crohn's disease risk and phenotype in diverse populations: a meta analysis. Am J Gastroenterol. 2004; 99: 2393-2404.

5. Yamazaki K, Onouchi Y, Takazoe M, Kubo M, Nakamura Y, Hata A Association analysis of genetic variants in IL23R, ATG16L1 and 5p13.1 loci with Crohn's disease in Japanese patients. J Hum Genet. 2007; 52: 575-83.

6. Yang SK, Park M, Lim J, Park SH, Ye BD, Lee I, et al. Contribution of IL23R but not ATG16L1 to Crohn's disease susceptibility in Koreans. Inflamm Bowel Dis. 2009; 15: 1385-1390.

7. Bin C, Zhirong Z, Xiaoqin W, Minhu C, Mei L, Xiang G, et al. Contribution of rs11465788 in IL23R gene to Crohn's disease susceptibility and phenotype in Chinese population. J Genetics. 2009; 88: 191-196.

8. Jürgens $M$, Laubender RP, Hartl F, Weidinger M, Seiderer J, Wagner J, et al. Disease activity, ANCA, and IL23R genotype status determine early response to infliximab in patients with ulcerative colitis. Am J Gastroenterol. 2010; 105: 1811-1819.

9. Barrett JC, Hansoul S, Nicolae DL, Cho JH, Duerr RH, Rioux JD, et al. Genome-wide association defines more than 30 distinct susceptibility loci for Crohn's disease. Nat Genet. 2008; 40: 955-962.

10. Parkes M, Barrett JC, Prescott NJ, Tremelling M, Anderson CA, Fisher SA et al. Sequence variants in the autophagy gene IRGM and multiple other replicating loci contribute to Crohn's disease susceptibility. Nat Genet. 2007; 39: 830-832.

11. Cheon JH. Genetics of inflammatory bowel diseases: a comparison between Western and Eastern perspectives. J Gastroenterol Hepatol. 2013; 28: 220 226 .

12. Prescott NJ, Dominy KM, Kubo M, Lewis CM, Fisher SA, Redon R, et al. Independent and population-specific association of risk variants at the IRGM locus with Crohn's disease. Hum Mol Genet. 2010; 19: 1828-1839.

13. Moon CM, Shin DJ, Kim SW, Son NH, Park A, Park B, et al. Associations between genetic variants in the IRGM gene and inflammatory bowel diseases in the Korean population. Inflamm Bowel Dis. 2013; 19: 106-114.

14. Bernstein CN, El-Gabalawy $\mathrm{H}$, Sargent M, Landers C, Rawsthorn $\mathrm{P}$, Elias $B$, et al. Assessing inflammatory bowel disease associated antibodies in Caucasian and First Nations cohorts. Can J Gastroenterol. 2011; 25: 269 273

15. Lakatos PL, Papp M, Rieder F. Serologic anti glycan antibodies in inflammatory bowel disease. Am J Gastroenterol. 2011; 106: 406-412.

16. Bogdanos DP, Rigopoulou EI, D. S. Smyk DS, Roggenbuck D, Reinhold D, Forbes A, et al. Diagnostic value, clinical utility and pathogenic significance of reactivity to the molecular targets of Crohn's disease specific-pancreatic autoantibodies. Autoimmunity Reviews. 2011; 11: 143-148.

17. Zholudev A, Zurakowski D, Young W, Leichtner A, Bousvaros A. Serologic testing with ANCA, ASCA, and anti-OmpC in children and young adults with Crohn's disease and ulcerative colitis: diagnostic value and correlation with disease phenotype. Am J Gastroenterol. 2004, 99: 2235-2241.

18. Fagerhol MK, Dale I, Andersson T. A radioimmunoassay for a granulocyte protein as a marker in studies on the turnover of such cells. Bull Eur Physiopathol Respir. 1980; 16: 273-282.

19. Waugh N, Cummins E, Royle P, Kandala NB, Shyangdan D, Arasaradnam $\mathrm{R}$, et al. Faecal calprotectin testing for differentiating amongst inflammatory and non-inflammatory bowel diseases: systematic review and economic evaluation. Health Technol Assess. 2013; 17: xv-xix, 1-211.

20. Røseth AG, Fagerhol MK, Aadland E, Schjønsby H. Assessment of the neutrophil dominating protein calprotectin in feces. A methodologic study. Scand J Gastroenterol. 1992; 27: 793-798.

21. Rump JA, Schölmerich J, Gross V, Roth M, Helfesrieder R, Rautmann A, et al. A new type of perinuclear anti-neutrophil cytoplasmic antibody (p-ANCA) in active ulcerative colitis but not in Crohn's disease. Immunobiology. 1990; 181(4-5): 406-413.

22. Joossens S, Reinisch W, Vermeire S, Sendid B, Poulain D, Peeters M, et al. The value of serologic markers in indeterminate colitis: a prospective followup study. Gastroenterology. 2002; 122: 1242-1247.

23. Zhou F, Xia B, Wang F, Shrestha U K, Min C, HongLin W, et al. The prevalence and diagnostic value of perinuclear antineutrophil cytoplasmic antibodies and anti-Saccharomyces cerevisiae antibodies in patients with inflammatory bowel disease in mainland China. Clin Chim Act. 2010, 411: $1461-1465$

24. Main J, McKenzie H, Yeaman GR, Kerr MA, Robson D, Pennington CR, et al. Antibody to Saccharomyces cerevisiae (bakers' yeast) in Crohn's disease. BMJ. 1988; 297: 1105-1106.

25. Prideaux L, De Cruz P, Ng SC, Kamm MA. Serological antibodies in inflammatory bowel disease: a systematic review. Inflamm Bowel Dis. 2012; 18: $1340-1355$

26. Mokhtarifar A, Ganji A, Sadrneshin M, Bahari A, Esmaeilzadeh A, Ghafarzadegan K, Nikpour S. Diagnostic Value of ASCA and Atypical p-ANCA in Differential Diagnosis of In? Middle East J Dig Dis. 2013; 5: 93-97.

27. Smith LA, Gaya DR. Utility of faecal calprotectin analysis in adult inflammatory bowel disease. World J Gastroenterol. 2012; 18: 6782-6789.

28. von Roon AC, Karamountzos L, Purkayastha S, Reese GE, Darzi AW, Teare $J P$, et al. Diagnostic precision of fecal calprotectin for inflammatory bowe disease and colorectal malignancy. Am J Gastroenterol. 2007; 102: 803-813.

29. van Rheenen PF, Van de Vijver E, Fidler V. Faecal calprotectin for screening of patients with suspected inflammatory bowel disease: diagnostic metaanalysis. BMJ. 2010; 341: c3369.

30. Sipponen T, Savilahti E, Kolho KL, Nuutinen H, Turunen U, F"arkkil"a M. Crohn's disease activity assessed by fecalcal protect in and lactoferrin: correlation with Crohn's disease activity index and endoscopic findings. Inflamm Bowel Dis. 2008; 14: 40-46.

31. Ricanek P, Brackmann S, Perminow G, Lyckander LG, Sponheim J, Holme $\mathrm{O}$, et al. Evaluation of disease activity in IBD at the time of diagnosis by the use of clinical, biochemical, and fecal markers. Scand J Gastroenterol. 2011; 46: 1081-1091.

32. Sipponen T, Bjrkesten CGA, F"arkkila M, Nuutinen H, Savilahti E, Kolho $\mathrm{KL}$. Faecal calprotectin and lactoferrinare reliable surrogate markers of endoscopic response during Crohn's disease treatment. Scand J Gastroenterol. 2010; 45: 325-331.

33. Sipponen T, Savilahti E, Kärkkäinen $P$, Kolho $K L$, Nuutinen $H$, Turunen $U$, et al. Fecal calprotectin, lactoferrin, and endoscopic disease activity in monitoring anti-TNF-alpha therapy for Crohn's disease. Inflamm Bowel Dis. 2008; 14: 1392-1398 
34. Røseth AG, Aadland E, Grzyb K. Normalization off aecal calprotectin: a predictor of mucosal healing in patients with inflammatory bowel disease. Scand J Gastroenterol. 2004; 39: 1017-1020.

35. Koulaouzidis A, Douglas S, Rogers MA, Arnott ID, Plevris JN. Fecal calprotectin: a selection tool for small bowel capsule endoscopy in suspected IBD with prior negative bi-directional endoscopy. Scand J Gastroenterol. 2011; 46: 561-566.

36. Kane SV, Sandborn WJ, Rufo PA, Zholudev A, Boone J, Lyerly D, et al. Fecal lactoferrin is a sensitive and specific marker in identifying intestinal inflammation. Am J Gastroenterol. 2003; 98: 1309-1314.

37. Sugi K, Saitoh O, Hirata I, Katsu K. Fecal lactoferrin as a marker for disease activity in inflammatory bowel disease: comparison with other neutrophilderived proteins. Am J Gastroenterol. 1996; 91: 927-934.

38. Joishy M, Davies I, Ahmed M, Julie W, Karen D, Sayers, et al. Fecal calprotectin and lactoferrin as noninvasive markers of pediatric inflammatory bowel disease. J Pediatric Gastroenterol Nutrition. 2009; 48: 48-54.

39. Langhorst J, Elsenbruch S, Koelzer J, Rueffer A, Michalsen A, Dobos GJ. Noninvasive markers in the assessment of intestinal inflammation in inflammatory bowel diseases: performance of fecal lactoferrin, calprotectin, and PMN-elastase, CRP, and clinical indices. Am J Gastroenterol. 2008; 103 162-169.

40. Nancey S, Boschetti G, Moussata D, Cotte E, Peyras J, Cuerq C, Haybrard $\mathrm{J}$, et al. Neopterin is a novel reliable fecal marker as accurate as calprotectin for predicting endoscopic disease activity in patients with inflammatory bowe diseases. Inflamm Bowel Dis. 2013; 19: 1043-1052.

41. Tillett WS, Francis T. Serological reactions in pneumonia with a non-protein somatic fraction of pneumococcus. J Exp Med. 1930; 52: 561-571.

42. Rudolph WG, Uthoff SM, McAuliffe TL, Goode ET, Petras RE, Galandiuk S. Indeterminate colitis: the real story. Dis Colon Rectum. 2002; 45: 1528-1534.

43. Abdelrazeq AS, Wilson TR, Leitch DL, Lund JN, Leveson SH. Ileitis in ulcerative colitis: is it a backwash? Dis Colon Rectum. 2005; 48: 2038-2046.

44. Yamamoto-Furusho JK, Camacho-Escobedo J, T'ellez-'Avila F, Barreto R Serum levels of beta2 microglobulin levels and high sensitive C-reactive protein as markers of histological activity in patients with chronic idiopathic ulcerative colitis. Gac Med Mex. 2010, 146: 31-35.

45. Chang S, Malter L, Hudesman D. Disease monitoring in inflammatory bowel disease. World J Gastroenterol. 2015; 21: 11246-11259.

46. Soubières $A A$, Poullis $A$. Emerging role of novel biomarkers in the diagnosis of inflammatory bowel disease. World J Gastrointest Pharmacol Ther. 2016 7: $41-50$.

47. Vermeire S, Van Assche G, Rutgeerts P. Laboratory markers in IBD: useful, magic, or unnecessary toys? Gut. 2006; 55: 426-431.

48. Danese S, Motte Cd Cde L, Fiocchi C. Platelets in inflammatory bowel disease: clinical, pathogenic, and therapeutic implications. Am J Gastroenterol. 2004; 99: 938-945.

49. Collins CE, Rampton DS. Platelet dysfunction: a new dimension in inflammatory bowel disease. Gut. 1995; 36: 5-8.

50. Dong WG, Liu SP, Zhu HH, Luo HS, Yu JP. Abnormal function of platelets and role of angelica sinensis in patients with ulcerative colitis. World $J$ Gastroenterol. 2004; 10: 606-609.

51. Kayahan H, Akarsu M, Ozcan MA, Demir S, Ates H, Unsal B, et al. Reticulated platelet levels in patients with ulcerative colitis. Int J Colorectal Dis. 2007; 22 $1429-1435$.

52. Kapsoritakis AN, Koukourakis MI, Sfiridaki A, Potamianos SP , Kosmadaki G Koutroubakis IE, et al. Mean platelet volume: a useful marker of inflammatory bowel disease activity. Am J Gastroenterol. 2001; 96: 776-781.

53. Zubcevic N, Mesihovic R, Zubcevic S. Usefulness of laboratory data in estimation of Crohn's disease activity. Med Arh. 2010; 64: 33-36.

54. Karnad A, Poskitt TR. The automated complete blood cell count. Use of the red blood cell volume distribution width and mean platelet volume in evaluating anemia and thrombocytopenia. Archives Intern Med. 1985, 145: 1270-1272

55. Oustamanolakis P, Koutroubakis IE, Messaritakis I, Kefalogiannis G, Niniraki $\mathrm{M}$, Kouroumalis EA. Measurement of reticulocyte and red blood cell indices in the evaluation of anemia in inflammatory bowel disease. J Crohns Colitis. 2011; 5: 295-300.

56. Kaiser T, Langhorst J, Wittkowski H, Becker K, Friedrich AW, Rueffer A, et al Faecal S100A12 as a non-invasive marker distinguishing inflammatory bowel disease from irritable bowel syndrome. Gut. 2007; 56: 1706-1713.

57. Mendoza JL, Abreu MT. Biological markers in inflammatory bowel disease: practical consideration for clinicians. Gastroenterol Clin Biol. 2009; 33: S158-S173.

58. Manolakis AC, Kapsoritakis AN, Georgoulias P, Tzavara C, Valotassiou $\mathrm{V}$, Kapsoritaki A, et al. Moderate performance of serum S100A12, in distinguishing inflammatory bowel disease from irritable bowel syndrome. BMC Gastroenterol. 2010; 10: 118.

59. Maor I, Rainis T, A. Lanir A, Lavy A. Adenosine deaminase activity in patients with Crohn's disease: distinction between active and non active disease. European J Gastroenterol Hepatol. 2011, 23: 598-602.

60. Lakatos PL, Kiss LS, Palatka K, Altorjay I, Antal-Szalmas P, Palyu E, et al. Serum lipopolysaccharide-binding protein and soluble CD14 are markers of disease activity in patients with Crohn's disease. Inflamm Bowel Dis. 2011; 17: 767-777.

61. Shinzaki S, Kuroki E, lijima H, Tatsunaka N, Ishii M, Fuji H, et al. Lectinbased immunoassay for aberrant IgG glycosylation as the biomarker for Crohn's disease. Inflamm Bowel Dis. 2013; 19: 321-331.

62. Li H, Tago K, lo K, Kuroiwa K, Arai T, Iwahana H, et al. The cloning and nucleotide sequence of human ST2L cDNA. Genomics. 2000; 67: 284-290

63. Díaz-Jiménez D, Núñez LE, Beltrán CJ, Candia E, Suazo C, Alvarez-Lobos $M$, et al. Soluble ST2: a new and promising activity marker in ulcerative colitis. World J Gastroenterol. 2011; 17: 2181-2190.

64. Stallhofer J, Friedrich M, Konrad-Zerna A, Wetzke M, Lohse P, Glas J, et al. Lipocalin-2 Is a Disease Activity Marker in Inflammatory Bowel Disease Regulated by IL-17A, IL-22, and TNF-a and Modulated by IL23R Genotype Status. Inflamm Bowel Dis. 2015; 21: 2327-2340.

65. Zhang S, Luo J, Shen, Li L, Hu C, Li P, et al. Correlation between triggering receptor expressed on myeloid cells- 1 and clinical disease activity in Chinese patients with ulcerative colitis. Int J Clin Exp Med. 2015; 8: 2147-2155.

66. Tavano F, di Mola FF, Latiano A, Palmieri O, Bossa F, Valvano MR, et al Neuroimmune interactions in patients with inflammatory bowel diseases: disease activity and clinical behavior based on Substance Pserum levels. J Crohn's \& Colitis. 2012, 6: 563-570.

67. Owczarek D, Undas A, Foley JH, Nesheim ME, Jablonski K, MachT. Activated thrombin activatable fibrinolysis inhibitor (TAFla) is associated with inflammatory markers in inflammatory bowel diseases TAFla level in patients with IBD. J Crohn's \& Colitis. 2012, 6: 13-20.

68. Nakarai A, Kato J, Hiraoka S, Kuriyama M, Akita M, Hirakawa T, et al Evaluation of mucosal healing of ulcerative colitis by a quantitative fecal immunochemical test. Am J Gastroenterol. 2013; 108: 83-89.

69. Aomatsu T, Imaeda H, Matsumoto K, Kimura E, Yoden A, Tamai H, et al Faecal chitinase 3-like-1: a novel biomarker of disease activity in paediatric inflammatory bowel disease. Aliment Pharmacol Ther. 2011; 34: 941-948.

70. Oikonomou KA, Kapsoritakis AN, Kapsoritaki Al, Manolakis AC, Tiaka EK, Tsiopoulos FD, et al. Angiogenin, angiopoietin-1, angiopoietin-2, and endostatin serum levels in inflammatory bowel disease. Inflamm Bowel Dis. 2011; 17: 963-970.

71. Ciorba MA. Indoleamine 2,3 dioxygenase in intestinal disease. Curr Opin Gastroenterol. 2013; 29: 146-152.

72. Scaldaferri F, Correale C, Gasbarrini A, Danese S. Mucosal biomarkers in inflammatory bowel disease: key pathogenic players or disease predictors? World J Gastroenterol. 2010; 16: 2616-2625. 
73. Judmaier G, Meyersbach P, Weiss G, Wachter H, Reibnegger G. The role of neopterin in assessing disease activity in Crohn's disease: classification and regression trees. Am J Gastroenterol. 1993; 88: 706-711.

74. Malerba M, Ragnoli B, Buffoli L, Radaeli A, Ricci C, Lanzarotto F, et al. Exhaled nitric oxide as a marker of lung involvement in Crohn's disease. Int $J$ Immunopathol Pharmacol. 2011; 24: 1119-1124.

75. Czub E, Herzig KH, Szaflarska-Poplawska A, Kiehne K, Socha P, Wos H, et al. Fecal pyruvate kinase: a potential new marker for intestinal inflammation in children with inflammatory bowel disease. Scand J Gastroenterol. 2007; 42: $1147-1150$.

76. Hardt PD, Mazurek S, Toepler M, Schlierbach P, Bretzel RG, Eigenbrodt E, et al. Faecal tumour M2 pyruvate kinase: a new, sensitive screening tool for colorectal cancer. Br J Cancer. 2004; 91: 980-984.

77. Walkowiak J, Banasiewicz T, Krokowicz P, Hansdorfer-Korzon R, Drews M, Herzig KH. Fecal pyruvate kinase (M2-PK): a new predictor for inflammation and severity of pouchitis. Scand J Gastroenterol. 2005; 40: 1493-1494.

78. Ludwig K, Fassan M, Mescoli C, Pizzi M, Balistreri M, Albertoni L, et al PDCD4/miR-21 dysregulation in inflammatory bowel disease-associated carcinogenesis. Virchows Arch. 2013; 462: 57-63.

79. Olaru AV, Selaru FM, Mori Y, Vazquez C, David S, Paun B, et al. Dynamic changes in the expression of MicroRNA-31 during inflammatory bowe disease-associated neoplastic transformation. Inflamm Bowel Dis. 2011, 17 221-231.

80. Wu CW, Ng SS, Dong YJ, Ng SC, Leung WW, Lee CW, et al. Detection of miR-92a and miR-21 in stool samples as potential screening biomarkers for colorectal cancer and polyps. Gut. 2012; 61: 739-745.

81. Chen CC, Pekow J, Llado V, Kanneganti M, Lau CW, Mizoguchi A, et al Chitinase 3-like-1 expression in colonic epithelial cells as a potentially novel marker for colitis-associated neoplasia. Am J Pathol. 2011; 179 : 1494-1503.
82. Vande Casteele N, Gils A. Pharmacokinetics of anti-TNF monoclonal antibodies in inflammatory bowel disease: Adding value to current practice. $J$ Clin Pharmacol. 2015; 55: S39-S50.

83. Nanda KS, Cheifetz AS, Moss AC. Impact of antibodies to infliximab on clinical outcomes and serum infliximab levels in patients with inflammatory bowel disease (IBD): a meta-analysis. Am J Gastroenterol. 2013; 108: 40-47.

84. Ward MG, Thwaites PA, Beswick L, Hogg J, et al. Intra-patient variability in adalimumab drug levels within and between cycles in Crohn's disease. Aliment Pharmacol Ther. 2017; 45: 1135-1145.

85. González-Lama Y, Bermejo F, López-Sanromán A, García-Sánchez V, Esteve M, Cabriada JL, et al. Thiopurine methyl-transferase activity and azathioprine metabolite concentrations do not predict clinical outcome in thiopurine-treated inflammatory bowel disease patients. Aliment Pharmacol Ther. 2011; 34: 544-554.

86. Gifford AE, Berg AH, Lahiff C, Cheifetz AS, Horowitz G, Moss AC. A random urine test can identify patients at risk of mesalamine non-adherence: a prospective study. Am J Gastroenterol. 2013; 108: 249-255.

87. Potocnik U, Ferkolj I, Glavac D, Dean M. Polymorphisms in multidrug resistance 1 (MDR1) gene are associated with refractory Crohn disease and ulcerative colitis. Genes \&Immunity. 2004; 5: 530-539.

88. Daniel F, Loriot MA, Seksik P, Cosnes J, Gornet JM, Lémann M, et al Multidrug resistance gene-1 polymorphisms and resistance to cyclosporine A in patients with steroid resistant ulcerative colitis. Inflamm Bowel Dis. 2007; 13: $19-23$.

89. Hlavaty T, Pierik M, Henckaerts L, Ferrante M, Joossens S, van Schuerbeek $\mathrm{N}$, et al. Polymorphisms in apoptosis genes predict response to infliximab therapy in luminal and fistulizing Crohn's disease. Aliment Pharmacol Ther. 2005; 22: 613-626.
Austin J Gastroenterol - Volume 4 Issue 2 - 2017

ISSN : 2381-9219 | www.austinpublishing group.com

Bahgat et al. (C) All rights are reserved
Citation: Bahgat MH and El-Etreby SA. Bio-Markers of Inflammatory Bowel Disease: Past, Present, and Future. Austin J Gastroenterol. 2017; 4(2): 1082. 